\section{Salmonella Infection of Ovarian Dermoid Cyst}

Salmonella infections of liver, spleen, peritoneum, and bone associated with enteric fever have been recorded but infection of an ovarian cyst, a case of which we report here, is rare. ${ }^{1-5}$

\section{Case Report}

A 19-year-old girl was admitted with a 10-day history of fever, vomiting and abdominal pain together with swelling of the lower abdomen for the past 24 hours. On admission she was toxic, with fever of $39 \cdot 4^{\circ} \mathrm{C}$. Her haemoglobin was $4.3 \mathrm{~g} / \mathrm{dl}$ and the W.B.C. $42 \times 10^{9} / 1$. A large, rounded, smooth pelvic mass of cystic consistency and reaching almost to the umbilicus was felt on examination. On vaginal examination the mass filled the pouch of Douglas, and aspiration produced purulent fluid. A diagnosis of pelvic abscess was made and vaginal drainage was established. Salmonella paratyphi $A$ were cultured from the discharge and from the blood. Stool and urine cultures were negative. The Widal reaction was positive to a titre of $1 / 320$ for both $\mathrm{O}$ and $\mathrm{H}$ antigens of $S$. paratyphi $A$.

The response to chloramphenicol was good and the fever subsided, but after 10 days the temperature again rose and the patient complained of lower pelvic pain and swelling, despite the drainage. At laparotomy a left ovarian cyst was found and was removed. $S$. paratyphi $A$ was cultured from the contents, and the histopathology of the tumour was that of a dermoid cyst containing a mass of hair. The patient was discharged in good condition 15 days after operation. Six weeks later she was readmitted in coma and severely jaundiced. A diagnosis of homologous serum jaundice was made. After three days she regained consciousness and was discharged in good health a month later.

${ }^{1}$ Bland Sutton, J., Universal Medical Record, 1913, 3, 383.

2 O'Shansky, A. L., fournal of the American Medical Association, 1916, 66, 888.

${ }^{3}$ Hingorani, V., Nurula, R. K., and Bhalla, S., Obstetrics and Gynecology, $1963,22,118$.

${ }^{4}$ Brelje, M. C., and Garcia-Bunuel, R., Obstetrics and Gynecology, 1964, 24, 279.

${ }^{5}$ Fu-Hsiang Tai and Bon-Yu Chu, International fournal of Gynaecology and Obstetrics, 1971, 9, 36.

National Health Laboratory, Khartoum, Sudan

HASSAN SIDAHMED, DIP.BACT., Head of Department of Bacteriology

Khartoum Civil Hospital, Khartoum, Sudan

ABO HASSAN, D.G.o., Head of Department of Obstetrics and Gynaecology

\section{Useful Function of "Non- functioning'" Renal Homograft}

The removal of a renal homograft once it has ceased to function is widely practised; however, this may not always be judicious. One theoretical disadvantage is that renal tissue is removed which may be capable of producing erythropoietin. Thus patients undergoing haemodialysis who retain their own kidneys need fewer blood transfusions and may even have a lower morbidity than patients who have undergone bilateral nephrectomy. ${ }^{1}$

In the following case erythropoiesis was clearly more effective with the failed renal graft in situ than in the previous period, when the patient was anephric.

\section{Case History}

A 31-year-old man began regular haemodialysis in October 1968 because of rapidly progressive crescentic glomerulonephritis associated with circulating antiglomerular basement membrane (anti-G.B.M.) antibodies. There was no pulmonary haemorrhage at any time. Six months later he received a cadaveric renal homograft which was affected by recurrent glomerulonephritis causing graft failure. Haemodialysis was reinstituted after removal of the transplanted kidney.

In February 1970 he was given azathioprine $100 \mathrm{mg} /$ day for three months in an attempt to suppress production of anti-G.B.M. antibody. $\mathrm{H}$ is own kidneys were removed in January 1971 . Over the next year, while undergoing haemodialysis five times every two weeks, he needed an average of four blood transfusions a month to maintain his mean packed cell volume (P.C.V.)

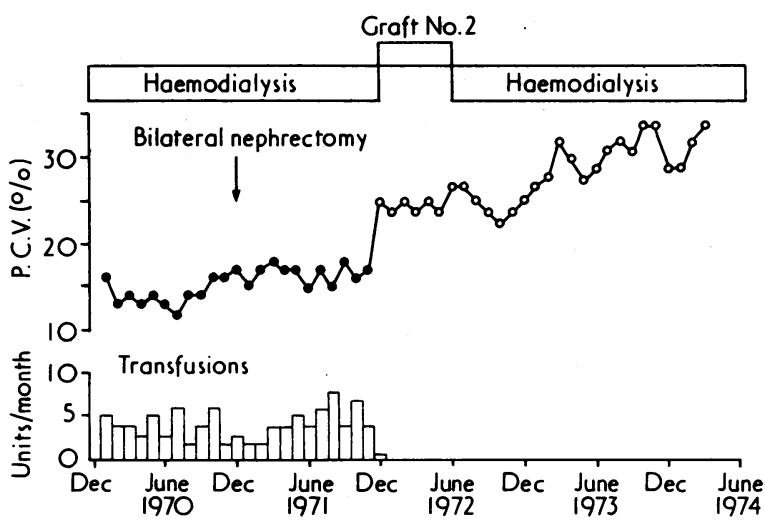

Packed cell volumes and number of blood transfusions needed.

at $15.4 \%$ (fig.). During this entire period he received testosterone $600 \mathrm{mg} /$ week intramuscularly and parenteral iron; serum iron ranged between 31 and $41 \mu \mathrm{mol} / 1(175$ and $226 \mu \mathrm{g} / 100 \mathrm{ml})$. There was no evidence of gastrointestinal bleeding at any time. He was normotensive and received no antihypertensive treatment.

A second cadaveric renal homograft operation was performed in January 1972. This kidney also developed recurrent anti-G.B.M. glomerulonephritis with progressive failure. Regular haemodialysis was reinstituted in July 1972. The grafted kidney, which produced no urine, was left in situ. Until the patient's accidental death 21 months later his P.C.V. averaged $28 \%$ and he needed no blood transfusions (fig). He remained normotensive without antihypertensive treatment.

\section{Comment}

In this case the presence of "non-functioning" renal tissue provided useful haemopoietic function, in that a higher P.C.V. was maintained without blood transfusions than when the patient was anephric. This probably resulted from erythropoietin production by the graft. Erythropoietic activity increases after renal transplantation ${ }^{2}$ and may remain raised despite the loss of renal function. ${ }^{3}$ Other metabolic functions may also be partially preserved by retaining the graft. Thus calcium absorption falls after bilateral nephrectomy in uraemic patients, ${ }^{4}$ presumably as a result of removal of the active site of conversion of 25-hydroxycholecalciferol to 1, 25-dihydroxycholecalciferol. A failed graft may therefore protect against the development of bone disease by retaining such function.

Definite indications for graft removal include local signs and symptoms related to graft rejection, infarction of the graft, and, possibly, the recent onset of severe hypertension which is difficult to control. When there is late graft failure its removal may rarely be necessary. In an analysis of 28 failed renal homografts retained after retransplantation, Gustafson et al. noted that only three had to be removed subsequently. Our case indicates that a failed renal homograft should be left in situ in the absence of definite indications for removal. Definite benefits may exist if a long period of haemodialysis is predicted.

This work was supported in part by USPHS Training Grant AM 5583, VA Study 1490-07.

Requests for reprints should be addressed to: Dr. J. W. Coburn, Nephrology Section 691/111L, VA Wadsworth Hospital Center, Wilshire and Sawtelle Blvds., Los Angeles, California 90073, U.S.A.

${ }^{1}$ Rao, T. K., et al., Transactions. American Society for Artificial Internal Organs, 1973, 19, 340.

${ }^{2}$ Hoffman, G. C., Annals of the New York Academy of Sciences, 1968, 149, 504

${ }^{3}$ Denny, W. F., Flanigan, W. J., and Zukoski, C. F., Fournal of Laboratory and Clinical Medicine, 1966, 67, 386.

4 Oettinger, C. W., et al., New England fournal of Medicine, 1974, 291, 458

5 Gustafsson, A., et al., Surgery, Gynecology, and Obstetrics, 1973, 137, 40.

Medical and Research Services, Veterans Administration Wadsworth

Hospital Center, Los Angeles, California 90073, U.S.A.

D. J. SHAPIRO, M.B., M.R.C.P., Clinical Associate in Nephrology UCLA School of Medicine, Los Angeles, California 90023

M. J. BLUMENKRANTZ, M.D., Assistant Professor of Medicine J. H. SHINABERGER, M.D., Associate Professor of Medicine J. W. COBURN, M.D., Professor of Medicine 